\title{
BETWEEN WORLDS
}

\section{The Enclosed Settlement of the Münchshöfen Culture at Riedling (Lower Bavaria)}

Márton Szilágyi - Ludwig Husty - Daniela Hofmann

Hungarian Archaeology Vol. 9 (2020), Issue 1, pp. 12-20, https://doi.org/10.36338/ha.2020.1.5

Our study presents a Late Neolithic enclosed settlement from Lower Bavaria. This site arouses interest not only regionally but also on a Central European level, as several phenomena emerged during this period along the Danube in Lower Bavaria that are strongly linked to the Carpathian Basin and other parts of Central Europe. In our present report, we focus on one phenomenon of the many at Riedling, the so-called structured deposits. These find assemblages are probably results of intentional selection of the material culture deposited deliberately, perhaps related to single ritual events.

\section{CHRONOLOGICAL AND CULTURAL SETTING - THE SECOND HALF OF THE 5TH MILLENNIUM BC}

Across Central and North-Western Europe, the Late Neolithic introduces fundamental changes in material culture and human behaviour. In addition, there is an expansion of the Neolithic way of life across the north European plain, into Great Britain and Ireland, and across the foothills of the Alps. A secondary expansion is also visible in regions that had been settled long before, where now less favourable soils were exploited (e. g. GLESER 1995, 331-335; Lichardus 1991).

Perhaps the biggest observable change in terms of material culture is the regional fragmentation in pottery styles. After the period of the culturally rather homogeneous LBK-complex (Linearbandkeramik, Linear Pottery culture), several cultural units emerged in this area that were distinguished mostly based on pottery, including the Rössen Group in southwestern Germany and in the Rhineland, the SBK (Stichbandkeramik, Stroked Pottery) in the north and northeast of the region (southern Germany, Czech Republic, southwestern Poland), and the Lengyel complex in the east (Moravia, Lower and Upper Austria, and the western Carpathian Basin) (e.g. Hofmann \& GLESER 2019).

In the second half of the 5th millennium cal BC, this cultural profile becomes even more fragmented, as does terminology. This period is assigned to the Late Neolithic in Germany, whereas it is called the Early Copper Age or Aeneolithic in the Carpathian Basin and adjacent areas. The appearance of the Epi-Rössen Groups (Aichbühl, Bischheim, Schussenried, Schwieberdingen, etc.; more recently the so-called 'Schulterbandgruppen') in the west were followed by the Michelsberg culture at the end of the period (GLESER 2016). The SBK is replaced by Gatersleben in Germany and by Jordanów/Jordansmühl in the Czech Republic and Poland (HofmAnn \& Gleser 2019, fig. 1). In the east, the image becomes pixelated too, with the appearance of the Lengyel III, Balaton-Lasinja, Sava, Ludanice, Bisamberg-Oberpullendorf and Kazianiberg-Lasinja groups (PAVÚK 2001; SRAKA 2012, 369-371). Nevertheless, these areas remain connected by a series of long-distance networks, along which (prestige) objects, such as those made of copper and gold, jade and other stone materials that can be knapped, and new technologies and ideas travelled (KLASSEN 2004; CHAPMAN 2013). Connecting these different scales of social action remains a central issue for archaeologists to investigate.

\section{THE MÜNCHSHÖFEN CULTURE IN BAVARIA}

In this brief report, we present one case study, the Bavarian Münchshöfen culture, which illustrates the complex interplay between local characteristics and a shared world view. While southeastern Bavaria had been an integral part of the LBK areas, in the first half of the 5th millennium the region was rather a contact zone located between the three large cultural blocks mentioned above, leading to a series of contradictory designations (Biermann 1997, 5-8; EiBl 2011; Riedhammer 2016, 128-129). This was followed, from the 5th millennium, by the Münchshöfen culture, a regional grouping centred on the Bavarian Danube valley. 
Münchshöfen is also defined mainly by its pottery style, characterised by the occurrence of a wide range of new pottery forms, new decoration techniques and ornamental motifs. It appeared along the Danube and its southern tributaries (Laber, Isar, Vils) in a fertile plain known as the Gäuboden, and in the Tertiary Hills area along the river valleys. Outside the core area, sporadic sites along the Lech River, around Salzburg and Upper Austria are also known (Süss 1976, 99-118; MeIXner 2017, abb 16.). Münchshöfen-type sherds have also been found further away, such as in Baden-Württemberg, the southern Alps, and the Czech Republic (ZÁpotocky 2016, 25; Motтes et al. 2002, 120).

This novel pottery style with its wide range of new pot shapes and decorations is very dissimilar from the previous period and is the defining characteristic of the Münchshöfen group. Main shapes include shouldered vessels, pots with cylindrical necks, bowls with thickened rims, small conical cups, and S-profiled bowls that often stood on high pedestals (Süss 1976, 6-39). Clay spoons or ladles are also common, identical in shape to those known from across Central Europe (Süss 1976, 35).

The decoration of the pots is spectacular, made mostly by using stab-and-drag technique. The motifs are usually built up from meander patterns that were arranged in panels around the bodies of the pots. These motifs occur only on certain types of pots, while other types have various plastic ornamentation and notches on the rim.

Although we know a large number of sites in Bavaria, many are stray finds and small-scale excavations. Generally speaking, the settlements were small in size, consisting of a few pits, and few traces of houses or buildings are known so far (GANSLmeier 2009; MeIXner 2016). Similarly, we do not yet know of any formal cemeteries, but instead a range of inhumations, partial and secondary burials from various kinds of sites. In addition, many of the 130 or so individuals known to date cannot be considered regular burials, for instance those buried in irregular positions in multiple interments (MEIXNER 2009). This is not unusual in a Late Neolithic context. Similarly, many sites have been discovered that were surrounded by enclosures or ditch systems, sometimes of substantial extent (Hofmann \& Husty 2019, 945-946), again in line with broader European trends. Some of these enclosures, but also some settlement sites, see so-called 'structured deposits', i.e. items of material culture thought to be deposited deliberately, perhaps for ritual purposes (HoFmann \& Husty 2019, 946-948).

There is little agreement on what brought about the development of the Münchshöfen phenomenon. It seems clear that this is a local group with strong relationships both to the east and the west, which is visible for example in the pottery style, structured deposits and the construction of enclosures (GLESER 1995, 290-298). However, this community was not open to all innovations, as neither the boom of copper and gold objects in the east nor the appearance of Alpine jade in the west had an impact on this area (KLASSEN et al. 2012, 1281).

Our project, generously funded by the Deutsche Forschungsgemeinschaft ${ }^{1}$, aims to study a single enclosure site with a rich inventory of finds in order to better understand the Münchshöfen culture and its connections to surrounding areas. Our main aims are to further characterise the network of contacts at the site (both in terms of objects and of behaviours), and to trace its chronological development. We also want to establish the role of this enclosure in its regional setting, whether enclosure sites can be said to function within a kind of settlement hierarchy, and if so, how stable this was. Finally, by drawing the strands together, we will reflect on the position of the Münchshöfen culture in its wider Late Neolithic European context, particularly in relation to narratives of increasing social stratification that are often linked to this period (HofmANN, Husty \& SZILÁGYi 2018, 168-169).

\section{RIEDLING-OBERPIEBING}

Our case study is the site of Riedling near Straubing in Lower Bavaria, located on a small rise between the Gäuboden and the Tertiary Hills (Husty \& Meixner 2009; Husty 2011). Excavation between 2007 and 2012 took place prior to clay mining and uncovered two intercutting ditches dated to the Münchshöfen

Chronology, networks, society: the Münchshöfen culture at the enclosure site of Riedling, Lower Bavaria. Grant number: 82751946. 
culture, in addition to a large number of pits mainly within the enclosures (Fig. 1).

The outer ditch is the earlier of the two. It forms an irregular oval of around $180 \mathrm{~m} \times 110 \mathrm{~m}$, which is unusually large for the Münchshöfen culture. The ditch is segmented, but taking into account the considerable levels of erosion at the site, the circuit was probably more continuous on the Neolithic ground surface, with only the larger gaps serving as entrances. The more recent, sub-rectangular ditch encloses an area of around $150 \mathrm{~m} \times 160 \mathrm{~m}$. It has not been completely excavated, but the remainder of its path has been traced through geophysical surveying. Overall, 169 Late Neolithic pits were excavated. Dozens more probably belonged to the same period, but they did not contain reliably datable finds.

The amount of finds - just like the size of the enclosure - is outstanding compared to other sites. The number of ceramic fragments is close to 45,000 and there are also thousands of animal bone finds. The weight of daub and burnt clay exceeds $180 \mathrm{~kg}$, and there are several hundred chipped and polished stone tools, as well as a variety of bone and textile production implements. Based on the ceramic material and the preliminary absolute dates, the site belongs to the classical and late Münchshöfen stylistic phases, and was in use between approximately 4400-4000 cal BC.

Due to the complexity of the site, and the quantity and significance of the finds, it stands out from other known Münchshöfen complexes. While a more comprehensive interpretation is still in pro-

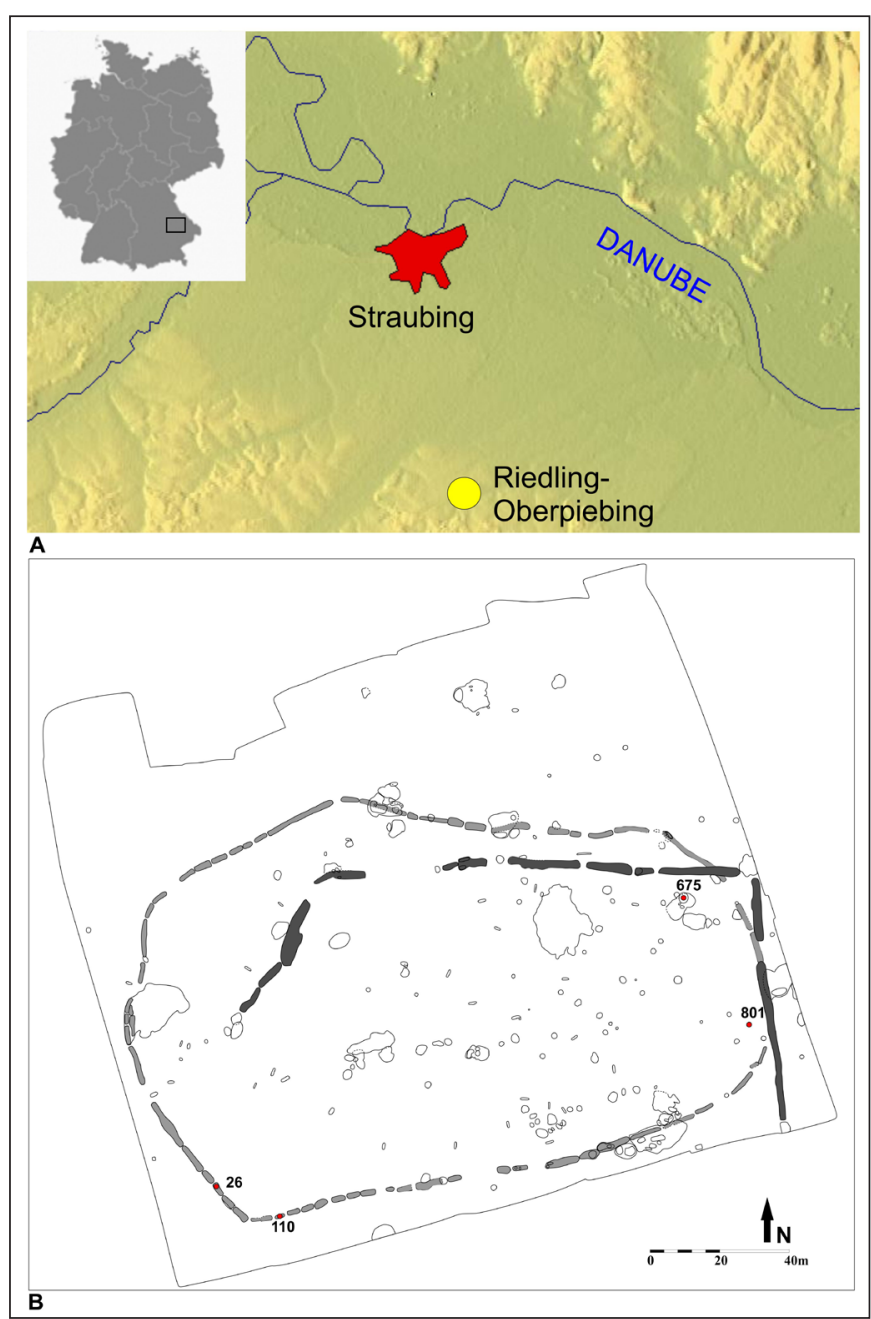

Fig. 1. The location of Riedling in southeastern Bavaria (above). Map of the Late Neolithic settlement (below). The segments of the earlier enclosure are coloured in light grey, the segments of the more recent enclosure are in dark grey, and features mentioned in the text are marked with red dots gress, in this publication we intend to present only one aspect in more detail, the structured deposits at Riedling and the role of pottery in them.

\section{STRUCTURED DEPOSITS IN RIEDLING}

Riedling has revealed a large number of special assemblages, defined on the basis of the quantity, completeness and composition of the material. Although the definitional boundaries of any category such as 'special' deposit must remain fuzzy, 25-30 pit assemblages have been provisionally identified as unusual. These were mostly recovered in segments of the older earthwork and some of the pits, and each assemblage appears to have been deposited over a very short period of time. They usually consisted of large amounts of fragmented pottery, animal bones, and in many cases human remains. In what follows, we will present four examples of structured deposits found in Riedling. They have been chosen to illustrate the diversity within this category, especially the variability of their find assemblages.

\section{Human remains and large quantities of pottery in ditch segment 26}

Feature 26 is located on the west side of the earlier enclosure, near its southwest corner. The segment is $4.2 \mathrm{~m}$ long, 1.4-1.7 m wide and only $40 \mathrm{~cm}$ deep. In the northern half of the oblong ditch segment, a human skeleton 
was found beneath a thick layer of fragmented pottery (Fig. 2 A). Charcoal and a small amount of daub were also deposited. The total weight of the pottery was more than $71 \mathrm{~kg}$, and the total amount of sherds ran to 1,773 pieces belonging to a maximum of 1152 vessels. In practice, this means that a relatively large number of cohesive fragments have been deposited here, proportionally more than the site average. Therefore, the pottery deposited here was in a less fragmented state than in most other features. However, the proportion of diagnostic sherds is lower than one would expect under these circumstances, mostly because the assemblage contains many large base and side fragments of otherwise undiagnostic pots. Among the identifiable pots are classic Münchshöfen forms (Fig. 2 B/6-9), but also rarities otherwise not found on the site or only sporadically. These include a small, shouldered tumbler, a bell-shaped pedestal and a short-necked spherical bowl (Fig. 2 B/3-5). It is also important to mention two miniature vessels, which are unusual in the site assemblage (Fig. 2 B/1-2).

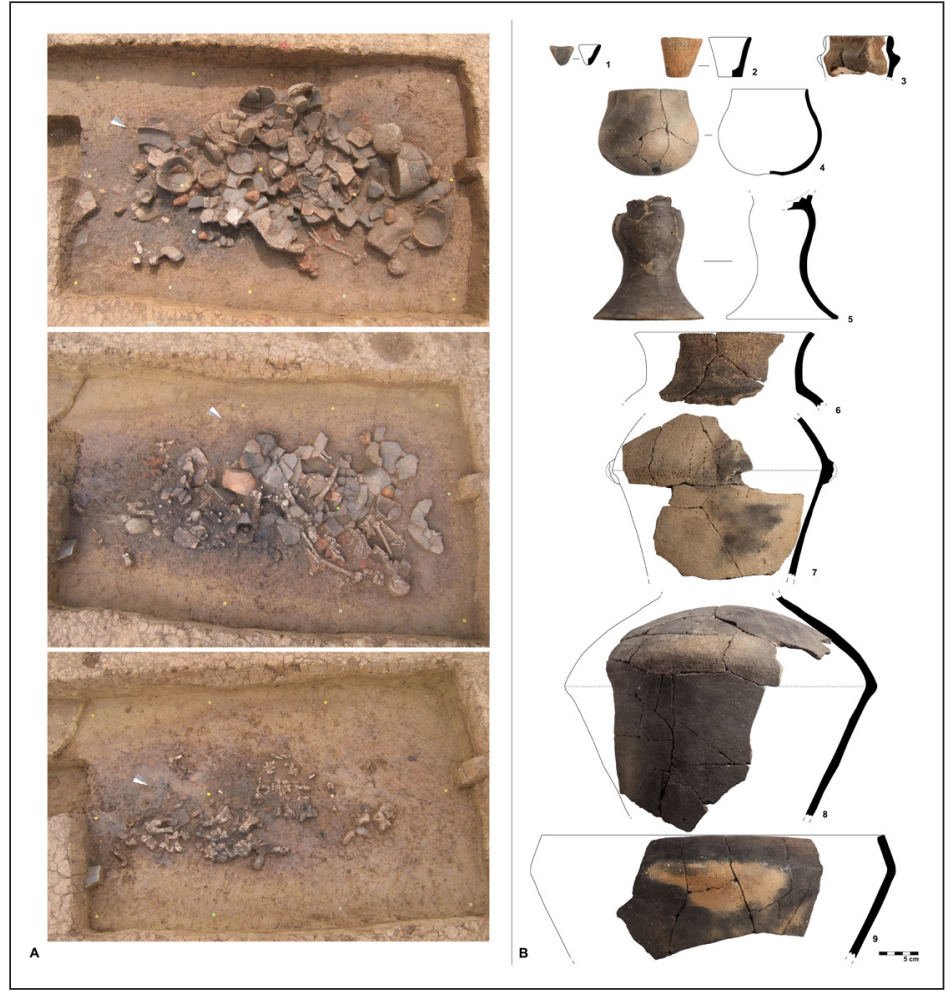

Fig. 2. A.: steps of uncovering ditch segment 26 (photograph: ArcTron);

B.: compilation of the pottery material from ditch segment 26

\section{Broken vessels in ditch segment 110}

Feature 110 is a short ditch segment, $2.5 \mathrm{~m}$ long, $0.9 \mathrm{~m}$ wide and only $20 \mathrm{~cm}$ deep. It is located at the south side of the earlier enclosure, near its southwest corner. An intact layer at the base of the feature contained a large amount of pottery, a few animal bones and daub (Fig. 3 A). The total amount of sherds ran to 901 fragments that belonged to a maximum of 454 pots. The total weight reached nearly $27 \mathrm{~kg}$. As in the previous example, the degree of fragmentation was lower than the average at the site, and the photographs show the large pieces of vessels at the base of the ditch.

The form and decoration of the vessels fit well into the classic Münchshöfen pottery style, with shouldered vessels, pots with cylindrical necks and bowls with thickened rims (Fig. 3 B/4-6). Some rare types were also found, such as a short-necked, semi-spherical bowl, a spherical jar with a narrowing neck, and a

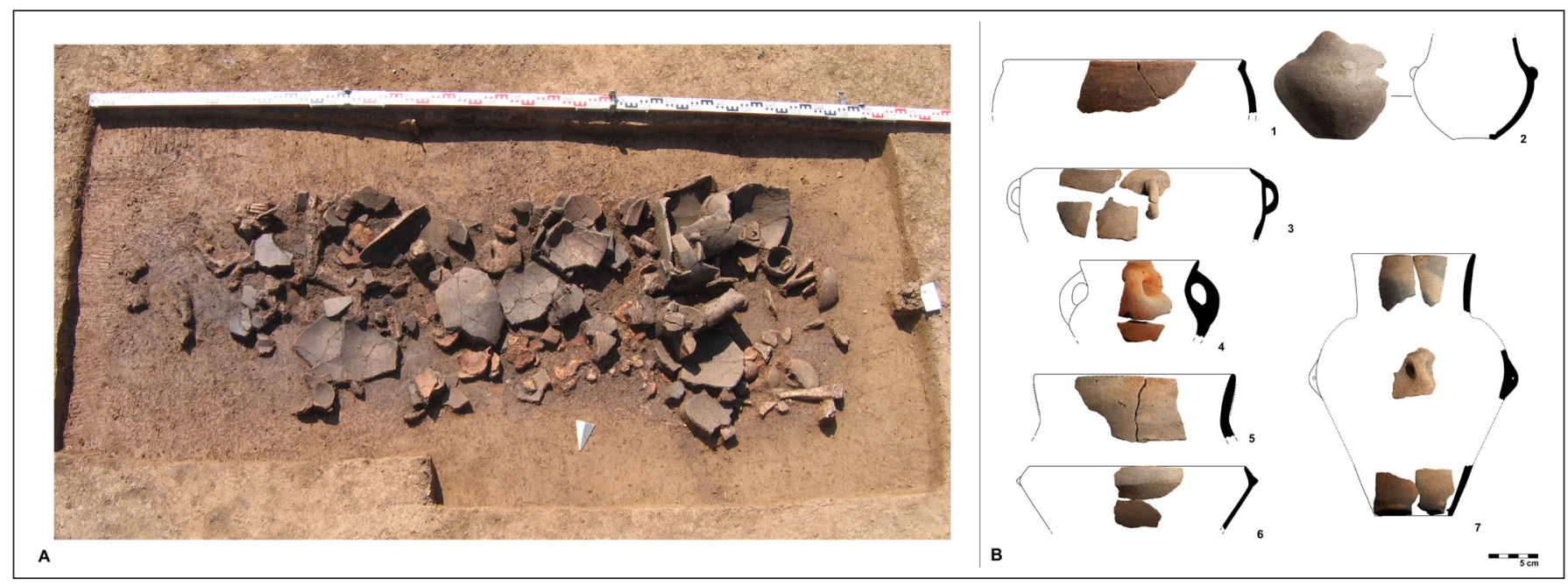

Fig. 3. A.: ditch segment 110 (photograph: ArcTron); B.: compilation of the pottery material from ditch segment 110 
Márton Szilágyi - Ludwig Husty - Daniela Hofmann • Between Worlds

bowl with handles (Fig. 3 B/1-3). Further fragments of the latter were found in a similar assemblage in the neighbouring ditch segment No. 109.

Human skulls and broken fine wares in pit 675

Feature 675 is a rounded pit with straight sides and a flat base, and is a part of a relatively small pit complex. Its diameter is $2.8-3 \mathrm{~m}$, its depth is $1.3 \mathrm{~m}$, making it larger than most other rounded pits at the site. A thin layer of charcoal was found at the base of the pit, on top of which was a large quantity of pottery and daub, three human skulls and other human bones, animal bones, a perforated bone tool and other finds (Fig. 4 A). The total number of sherds was 1280 , belonging to a maximum of 1219 pots. The total weight of the pottery was as much as $25 \mathrm{~kg}$.

A characteristic of the pottery assemblage recovered here was its high degree of fragmentation. The material consisted of mostly small fragments, so that relatively

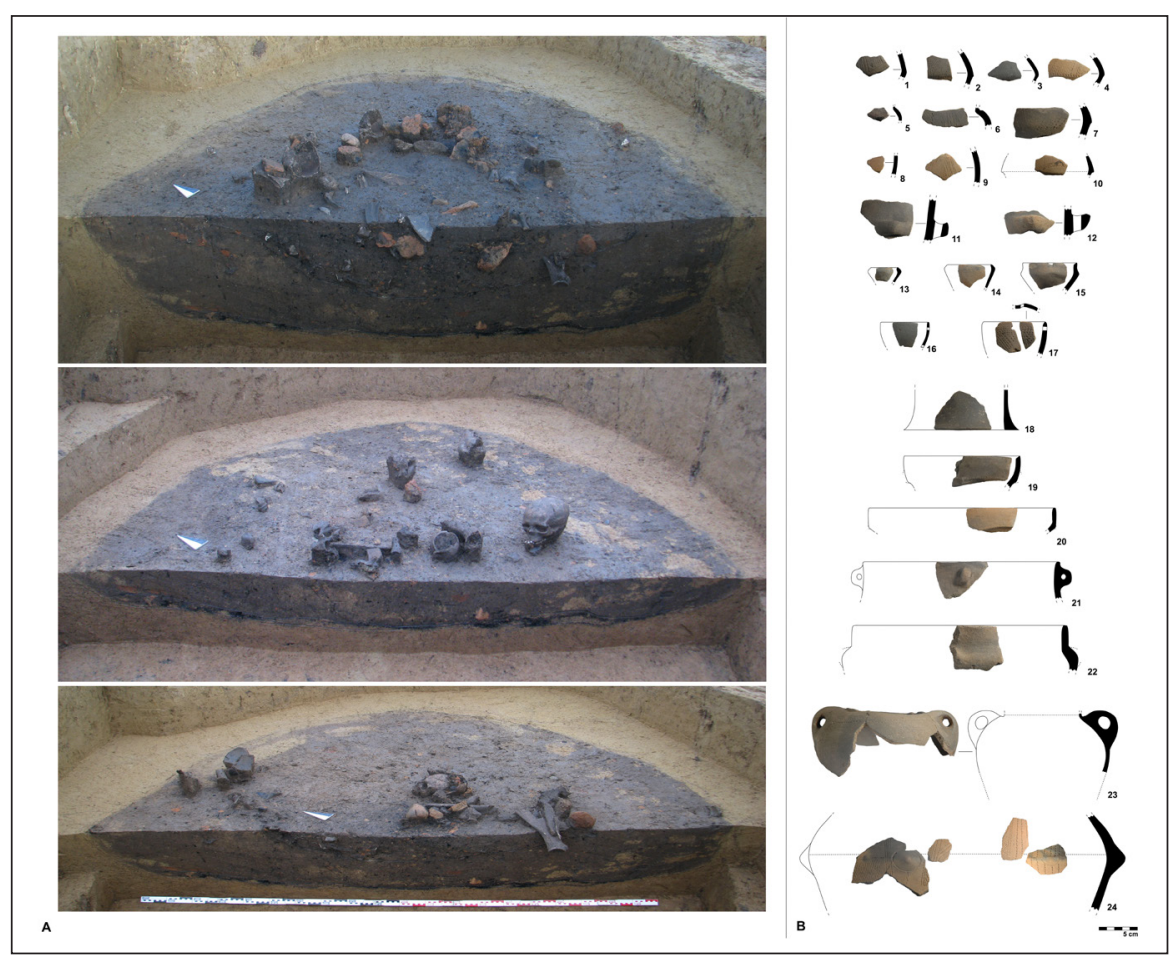

Fig. 4. A.: steps of uncovering pit 675 (photograph: ArcTron); B.: compilation of the pottery material from pit 675

few types could be identified. The proportion of decorated fragments was unusually high, almost $10 \%$ of all fragments were decorated with stab-and-drag motifs (Fig. 4 B). Large quantities of daub were also found; the total weight of the 381 fragments exceeded $13.5 \mathrm{~kg}$. Interestingly, one third of this material showed architectural imprints, again an unusually high number.

Grinding stones, potsherds and traces of fire in pit 801

Feature 801 is an irregularly shaped, rounded pit in the southeastern part of the site, a few meters from the inside edge of the earlier ditch. The pit has a diameter of $1.3 \mathrm{~m}$, which is larger than similar pits. At 1.6

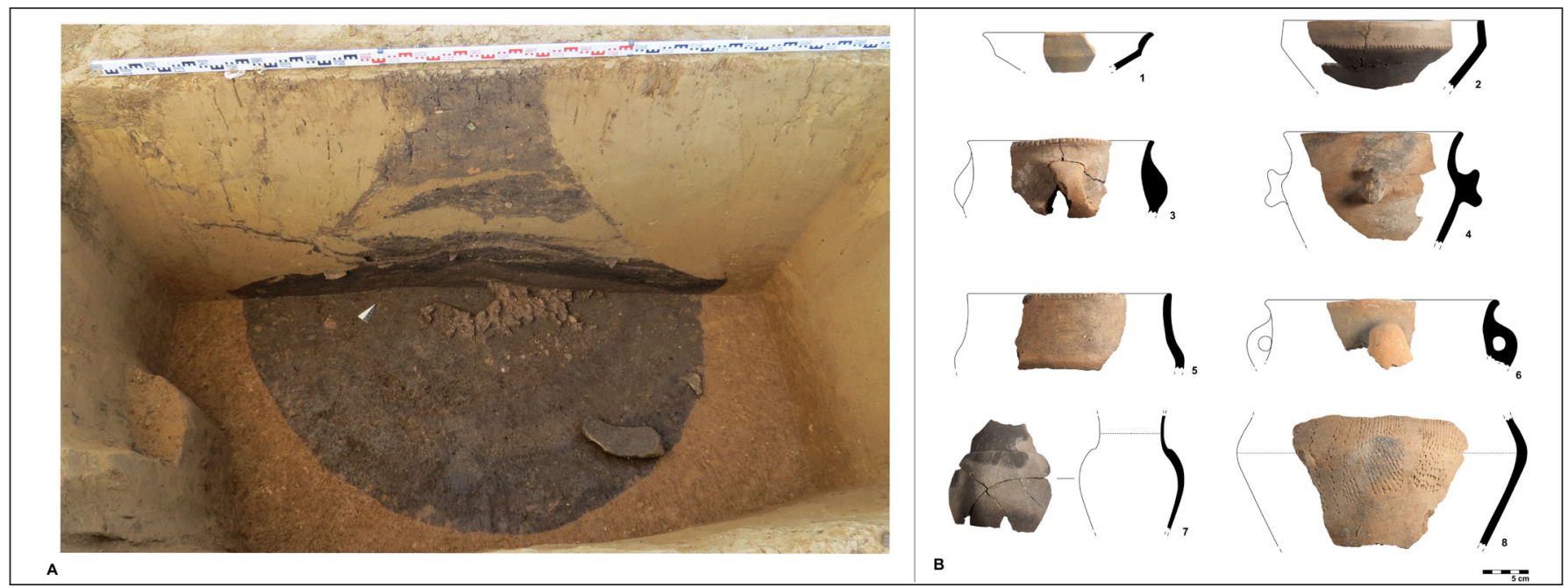

Fig. 5. A.: pit 801 (photograph: ArcTron); B.: compilation of the pottery material from pit 801 
$\mathrm{m}$, its depth differs significantly from the average of $0.3-0.6 \mathrm{~m}$ for similar features. A find concentration right at the base of the pit consisted of pottery, burnt earth, a few animal bones and daub, and fragments of grinding stones (Fig. 5 A). The amount of pottery ( 240 fragments from 193 vessels at most, total weight 5.8 $\mathrm{kg}$ ) is not very large, but still far exceeds the quantities usually found in similar pits. Among the identifiable pots are classic Münchshöfen forms, with shouldered vessels, pots with cylindrical necks, bowls with thickened rims and bowls with an S-shaped profile (Fig. 5 B). The assemblage also contained a relatively large proportion of fine wares. The amount of animal bones and daub is low or average, but the number of grinding stones is very high.

\section{IS THERE ANY ORDER? PATTERNS IN STRUCTURED DEPOSITION}

The examples presented here clearly show the duality that characterises structured deposits. On the one hand, there is a high degree of similarity of form. These assemblages were placed in the ground during a single event or over a very short time, as indicated by a compact layer or finds at the base or within the bottom third of the features. This suggests that the act of deposition was a single, conscious event. The selection of the locations might also have been deliberate, with most of the examples recorded in segments of the older ditch or in rounded, deep pits. It is also clear that the number of finds is much larger than for average settlement features. In all the cases cited here, pottery is a central element in the rituals. There also seems to be a deliberate selection of objects, which is indicated by rarer pottery forms and the fact that composition patterns differ from the average of all assemblages. Some of the pottery forms and decorations became generally used in the later phases of the settlement, thus the appearance of these objects can be seen as presenting novelties in a special context. However, some of the innovations dated to this period do not occur either elsewhere at Riedling or at other sites of the Münchshöfen culture.

On the other hand, there are also clear differences. The composition of the assemblages can vary considerably in terms of both type and condition of the finds. Human remains do not appear in all assemblages, and the range and quantity of animal bones, daub and stone artefacts show tremendous variety. Similarly, the precise characteristics of the pottery are highly variable. Rare shapes are common, the proportion of fine, decorated ceramics is many times higher than in average pits, and the level of fragmentation often suggests vessels in better condition. However, these principles cannot be considered exclusive, and are not always valid. The precise categories of vessels differed, sometimes placing more stress on exotic or carefully produced forms, and sometimes on sheer mass. In addition, some vessels were deposited almost complete and/or smashed in situ, while in other cases it seemed important to have as many different containers as possible represented, even if in small quantities.

\section{CONCLUSIONS AND OUTLOOK}

In this short study, we have highlighted some examples of a typical phenomenon of the site at Riedling, namely structured deposits. Overall, and even on the basis of such a small, preliminary selection, it is clear that structured deposits were an important arena for the consumption of wealth and innovation in ritual display. The role of pottery is central in this endeavour. Vast quantities of carefully produced and extensively decorated vessels were destroyed at such events, alongside rare and exotic forms and a huge number of more mundane containers for storage and food preparation. It is likely that in addition to any long-decayed organic vessels, we are also missing the former contents of these objects, food and drink for human consumption. Together, these represent an important part of this society's surplus production. It is possible that presenting food and drink to large gatherings of people in appropriately chosen containers was a socially valued activity that could have played a similar role as the deposits of prestige items such as metalwork in other contemporary cultures.

In this very short essay, we could only present a preliminary snapshot of our material. However, the issue will be further investigated, for example by testing the pots for their former contents and by further detailed comparison of the inventories of each deposit. We also hope to further contextualise the tradition of 
Márton Szilágyi - Ludwig Husty - Daniela Hofmann • Between Worlds

structured deposits as a whole. The Münchshöfen phenomenon has strong eastern connections, with many characteristics linking it to eastern Central Europe, including the western Carpathian Basin. This system of contacts has recently been referred to as the "Late Lengyel Interaction Zone". The westernmost section of this is southeastern Bavaria and the easternmost is the Carpathian Basin (CZERNIAK \& Pyzel 2016, 111; JeUNESSE 2019, 122-125). Thus, understanding the Late Neolithic in Bavaria may also be a crucial puzzle piece to understanding this wider sphere, including the Transdanubian Early Copper Age and the variety of new social forms that could exist within it.

\section{BIBLIOGRAPHY}

Biermann, E. (1997). Großgartach und Oberlauterbach. Interregionale Beziehungen im süddeutschen Mittelneolithikum. Archäologische Berichte 8. Bonn: Deutsche Gesellschaft für Ur- und Frügeschichte; Habelt.

Chapman, J. (2013). From Varna to Brittany via Csőszhalom - Was there a »Varna Effect «? In A. Anders, G. Kulcsár, with G. Kalla, V. Kiss \& G. V. Szabó (eds.), Moments in Time. Papers presented to Pál Raczky on his 60th birthday (pp. 323-335). Budapest: ELTE - L'Harmattan.

Czerniak, L. \& Pyzel, J. (2016). Being at home in the Early Chalcolithic. The longhouse phenomenon in the Brześć Kujawski Culture in the Polish Lowlands. Open Archaeology 2, 97-114. https://doi.org/10.1515/ opar-2016-0007

Eibl, F. (2011). Die Bayerische Gruppe der Stichbandkeramik und die Gruppe Oberlauterbach - zum Stand der Forschung. Fines Transire 20, 79-100.

Ganslmeier, R. (2009). Lost villages: Wallerdorf - ein Weilerhof der Münchshöfener Kultur. Bemerkungen zu terrestrischen Siedlungen der frühen Kupferzeit. In L. Husty, M. Rind \& K. Schmotz (eds.), Zwischen Münchshöfen und Windberg. Gedenkschrift für Karl Böhm (pp. 109-130). Rahden: Leidorf.

Gleser, R. (1995). Die Epi-Rössener Gruppen in Südwestdeutschland. Untersuchungen zur Chronologie, stilistischen Entwicklung und kulturellen Einordnung. Bonn: Habelt.

Gleser, R. (2016). Neue Überlegungen zur Chronologie der postbandkeramischen Kulturphänomene in Mitteleuropa. In J. Kovárník et al. (eds.), Centenary of Palliardi's Neolithic and Aeneolithic Relative Chronology (1914-2014) (pp. 107-116). Hradec Králové - Ústí nad Orlicí: University of Hradec Králové, Philosophical Faculty.

Hofmann, D. \& Gleser, R. (2019). The fifth millennium: The emergence of cultural diversity in Central European prehistory. In D. Hofmann \& R. Gleser (eds.), Contacts, Boundaries and Innovation in the Fifth Millennium. Exploring developed Neolithic societies in Central Europe and beyond (pp. 13-42). Leiden: Sidestone Press.

Hofmann, D. \& Husty, L. (2019). Enclosures, structured deposits and selective innovations: Riedling and the role of the South Bavarian Münchshöfen Culture in the new networks of the Late Neolithic. In J. Müller, M. Hinz \& M. Wunderlich (eds.), Megaliths - Societies - Landscapes. Early Monumentality and Social Differentiation in Neolithic Europe. Volume 3. Proceedings of the international conference »Megaliths Societies - Landscapes. Early Monumentality and Social Differentiation in Neolithic Europe« (16th-20th June 2015) in Kiel (pp. 939-956). Bonn: Habelt. 
Márton Szilágyi - Ludwig Husty - Daniela Hofmann • Between Worlds

Hofmann, D., Husty, L. \& Szilágyi, M. (2018). Chronologie, Vernetzungen, Sozialstrukturen: Das Erdwerk von Riedling, Niederbayern, und seine Rolle im Jungneolithikum Mitteleuropas. In F. Nikulka, D. Hofmann \& R. Schumann (eds.), Menschen-Dinge-Orte. Aktuelle Forschungen des Instituts für Vor-und Frühgeschichtliche Archäologie der Universität Hamburg (pp. 163-170). Hamburg: Institut für Vor- und Frühgeschichtliche Archäologie, Universität Hamburg.

Husty, L. (2011). Südostbayern in der zweiten Hälfte des 5. Jahrtausends v. Chr. - Forschungsfortschritte der letzten 20 Jahre. Fines Transire 20, 129-147.

Husty, L. \& Meixner, G. (2009). Ein neues Münchshöfener Grabenwerk in Riedling, Gde. Oberschneiding, Lkr. Straubing-Bogen. Erster Vorbericht zu den archäologischen Grabungen des Jahres 2007. In K. Schmotz (ed.), Vorträge des 27. Niederbayerischen Archäologentages (pp. 29-63). Rahden: Leidorf.

Jeunesse, C. (2019). The fifth millennium BC in Central Europe. Minor changes, structural continuity: a period of cultural stability. In D. Hofmann \& R. Gleser (eds.), Contacts, Boundaries \& Innovation in the Fifth Millennium. Exploring developed Neolithic societies in Central Europe and beyond (pp. 105-128). Leiden: Sidestone Press.

Klassen, L. (2004). Jade und Kupfer. Untersuchungen zum Neolithisierungsprozess im westlichen Ostseeraum unter besonderer Berücksichtigung der Kulturentwicklung Europas 5500-3500 BC. Århus: Jutland Archaeological Society - Moesgård Museum.

Klassen, L., Cassen, S. \& Pétrequin, P. (2012). Alpine axes and early metallurgy. In P. Pétrequin, S. Cassen, M. Errera, L. Klassen, A. Sheridan et al. (eds.), Jade - Grandes haches alpines du Néolithique européen. Ve et IVe millénaires av. J.-C. (pp. 1280-1309). Les Cahiers de la MSHE Ledoux 17, Série Dynamiques Territoriales 6. Besançon: Presses Universitaires de Franche-Comté and Centre de Recherche archéologique de la Vallée de l'Ain.

Lichardus, J. (1991). Die Kupferzeit als historische Epoche. Versuch einer Deutung. In J. Lichardus, with R. Echt (eds.), Die Kupferzeit als historische Epoche. Teil 2. (pp. 763-800). Bonn: Habelt.

Meixner, D. (2009). Ausnahme oder Regel - Zum Phänomen der Münchshöfener Bestattungen. In K. Schmotz (ed.), Vorträge des 27. Niederbayerischen Archäologentages (pp. 91-144). Rahden: Leidorf.

Meixner, D. (2016). Fossae sub muris tectae - Neolithische Hausgrundrisse unter einer römischen villa rustica bei Gaimersheim, Lkr. Eichstätt (Oberbayern). In J. Pechtl, T. Link \& L. Husty (eds.), Neue Materialien des Bayerischen Neolithikums. Tagung im Kloster Windberg vom 21. bis 23. November 2014 (pp. 87-97). Würzburg: Würzburg University Press. https://doi.org/10.25972/WUP-978-3-95826-045-0

Meixner, D. (2017). Alles „klassisch“? Überlegungen zur inneren Chronologie der frühjungneolithischen Münchshöfener Kultur. Bayerische Vorgeschichtsblätter 82, 7-56.

Mottes, E., Nicolis, F. \& Schlichtherle, H. (2002). Kulturelle Beziehungen zwischen den Regionen nördlich und südlich der Zentralalpen während des Neolithikums und der Kupferzeit. In G. Schnekenburger (ed.), Über die Alpen. Menschen - Wege-Waren (pp. 119-135). Stuttgart: Theiss.

Pavúk, J. (2000). Das Epilengyel/Lengyel IV als kulturhistorische Einheit. Slovenská Archeológia 48 (1), $1-23$. 
Márton Szilágyi - Ludwig Husty - Daniela Hofmann •Between Worlds

Riedhammer, K. (2016). Zwischen Großgartach, Stichbandkeramik und Mährisch Bemalter Keramik. In J. Kovárník et al. (eds.), Centenary of Palliardi's Neolithic and Aeneolithic Relative Chronology (1914-2014) (pp. 127-148). Hradec Králové - Ústí nad Orlicí: University of Hradec Králové, Philosophical Faculty.

Sraka, M. (2012). 14C calendar chronologies and cultural sequences in 5th millennium BC in Slovenia and neighbouring regions. Documenta Praehistorica 39, 349-376. https://doi.org/10.4312/dp.39.26

Süss, L. (1976). Zur Münchshöfener Gruppe in Bayern. In H. Schwabedissen (ed.), Die Anfänge des Neolithikums vom Orient bis Nordeuropa. Teil Vb Westliches Mitteleuropa (pp. 1-121). Köln: Böhlau.

Zápotocký, M. (2016). Jordanovská kultúra na východě Čech. Die Jordanów-Kultur im Osten Böhmens. Památky Archeologické 107, 5-49. 